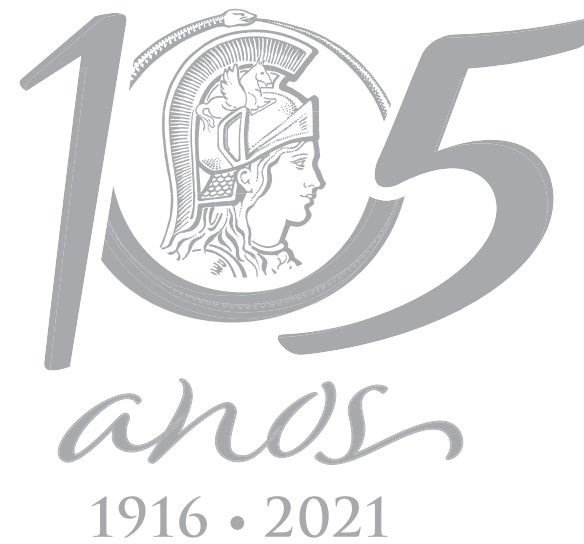

$1916 \cdot 2021$

\title{
Evaluation of antioxidant, cytotoxic, antibacterial effects and mineral levels of Verbascum lasianthum Boiss. ex Bentham
}

\author{
ÖMER HAZMAN, LAÇINE AKSOY, AHMET BÜYÜKBEN, RECEP KARA, MUSTAFA \\ KARGIOĞLU, ZEHRA B. KUMRAL \& IBRAHIM EROL
}

\begin{abstract}
The present study aimed to determine the antibacterial, antioxidant, cytotoxic activities and element levels of Verbascum lasianthum Boiss. ex Bentham. The free radical scavenging activity, total phenolic content, total antioxidant capacity, total oxidant capacity levels were analyzed as the antioxidant parameters. Seven bacteria and one yeast strains were used to determine the antimicrobial activity. The cytotoxic effects of plant extracts were determined using A549, MCF-7, HepG2 and SH-SY5Y cell lines. The findings demonstrated that the antioxidant activity increased with an increase in the phenolic content of extracts. This species is rich in bio-elements such as Fe, $\mathrm{Cu}$, $\mathrm{Mn}, \mathrm{Zn}$, and $\mathrm{Mg}$. Different concentrations of extracts could have antibacterial activity. This plant had an apparent cytotoxic effect only in the A549 cell line and increased the proliferation in other cell lines. The findings demonstrated that plant could be used alone or as a supplement to the current treatment protocols in diseases due to their antioxidant, antibacterial and cytotoxic effects. However, it is recommended that Verbascum L. species intended for use in therapy should be procured from areas where there is no soil pollution or organic farming is preferred.
\end{abstract}

Key words: Antibacterial activity, antioxidant, cytotoxic, Verbascum lasianthum Boiss. ex Bentham.

\section{INTRODUCTION}

Verbascum L. (Scrophulariaceae) species, known as verbasco, are frequently used in several countries due to its mucolytic effects, particularly in relieving the upper respiratory tract. However, different Verbascum species are used in the treatment of wounds, eczemas, hemorrhoids, and diarrhea in traditional medicine in different regions (Akdemir et al. 2011, Alipieva et al. 2014, Suntar et al. 2010, Kahraman et al. 2010). Thus, dried Verbascum L. leaves and flowers, oil extracts, alcoholic tinctures, capsules are sold as alternative medicine products in pharmacies and markets in most countries (Luca et al. 2019). There are about 360 types of Verbascum species globally and Turkey is the country with the most diversity (Bani et al. 2010). Verbascum lasianthum is a biennial herb widely grown in Turkey. Like many other Verbascum species, it is used for its mucolytic effects. It is also reported that the flowers of $V$. lasianthum are used for hemorrhoids in southwestern Anatolia (Tuzlacı \& Erol 1999). Antibacterial, antioxidant, cytotoxic effects and element levels of Verbascum lasianthum Boiss. ex Bentham species was investigated in the present study. 


\section{MATERIALS AND METHODS}

\section{Plant material}

Verbascum lasianthum Boiss. ex Benth. plant species were collected in Köroğlubeli $\left(38^{\circ} 58^{\prime} 59^{\prime \prime} \mathrm{N}, 30^{\circ} 55^{\prime} 29^{\prime \prime}\right)$, Afyonkarahisar on July, 2017. The plant was collected from the plateau in the high mountain area. Dr. Mustafa Kargıoğlu conducted identification of the plant. The genus and species identification of the plant sample was conducted based on Huber Morath. The plant sample is stored at Afyon Kocatepe University herbarium with the registration number AKU9323.

\section{Preparation of the plant extract}

A mixture of Verbascum lasianthum plant stem, leaves and flowers was used. These parts were cut to small pieces and dried. The dried pieces were grounded (crude sample) with a blender to prepare the plant extracts. Both methanol and acetone extracts of the plant were prepared. Verbascum lasianthum acetone $\left(\mathrm{VL}_{\text {acetone }}\right)$ and methanol $\left(\mathrm{VL}_{\text {methanol }}\right)$ extracts were produced with a Soxhlet extraction system. Extraction with Soxhlet continued for 8 hours. Free radical scavenging activity, total phenolic acid content, total antioxidant capacity (TAC), total oxidant capacity (TOC) levels, antimicrobial and cytotoxic effects were analyzed in the obtained extracts. Mineral levels were determined with crude plant samples.

\section{Antioxidant activity analyses}

\section{Free radical scavenging activity}

The free radical scavenging activity of the Verbascum lasianthum plant was conducted according to the method based on DPPH (1,1-diphenyl-2-picrylhydrazyl) radical scavenging. The radical scavenging activities of $\mathrm{VL}_{\text {acetone }}$ and $\mathrm{VL}_{\text {methanol }}$ extracts, BHT (Butylated hydroxy toluene) and $\alpha$-tocopherol were prepared at different concentrations (7.5, 15, $22.5 \mathrm{mg} / \mathrm{mL}$ ). DPPH solution (1 mM) was added to $100 \mu \mathrm{L}$ solutions. All samples were wrapped in aluminum foil and stored in the dark for 30 minutes. The absorbance of the samples was measured at $517 \mathrm{~nm}$ against the blank. While determining the DPPH radical scavenging effect, BHT (synthetic antioxidant) and $\alpha$-tocopherol (natural antioxidant) were used as positive controls. The same procedures were repeated with BHT and $\alpha$-tocopherol. Based on the optical density of plant extracts and antioxidants used for comparison, the percentage inhibition rates were calculated with the formula presented below.

$$
\begin{gathered}
\text { Inhibition rate }(\%)=\left[\text { Absorbance }_{\text {control }}-\right. \\
\text { Absorbance } \left.\left.\left._{\text {sample }}\right) / \text { Absorbance }_{\text {control }}\right)\right] \times 100
\end{gathered}
$$

Using the curve equations obtained from the percentage inhibition graphs, $I C_{50}$ values (the dose that inhibits $50 \%$ of DPPH in the solutions) were calculated for $\mathrm{VL}_{\text {acetone }}$ and $\mathrm{VL}_{\text {methanol }}$ extracts, BHT and tocopherol (Desmarchelier et al. 1997).

\section{Total phenolic acid content}

Total phenolic acid content was measured with the Folin-Ciocalteu method. A standard curve was plotted for gallic acid that is used to determine the phenolic acid content in plant extracts. While determining the total amount of phenolic substance, gallic acid was used as a control. Different concentrations (100, 250, 500, 700, 1000 $\mu \mathrm{g} / \mathrm{mL}$ ) of standard gallic acid solutions were prepared. Folin-Ciocalteu reagent was added to plant extracts and standard solutions. $\mathrm{Na}_{2} \mathrm{CO}_{3}$ was added and the product was stored at room temperature for 2 hours. The absorbance of the mixture was measured against the water with an UV spectrophotometer at $760 \mathrm{~nm}$ (Gamez Meza et al. 1999). Using the absorbance determined in the analysis of plant extracts and the accurate 
equation obtained with the gallic acid standard curve, the total phenolic acid content in $1 \mathrm{mg}$ extract was calculated as gallic acid equivalent ( $\mu \mathrm{g}$ GAE / mg).

\section{Total antioxidant capacity (TAC), total oxidant capacity (TOC) and oxidative stress index (OSI)}

Verbascum lasianthum acetone and methanol extract TAC and TOC levels were measured with commercial kits based on spectrophotometric method (Rel Assay, Gaziantep, Turkey). Extracts solutions with a concentration of $1 \mathrm{mg} / \mathrm{mL}$ were prepared in dimethyl sulfoxide (DMSO) for this purpose. DMSO was used as the blank in the analysis. Trolox determined as positive control for TAC. Sample TAC levels were determined by comparison with Trolox, a water-soluble form of vitamin E. Thus, the total antioxidants content of the samples was determined as Trolox equivalent. TAC levels were determined with a calibration curve developed based on Trolox antioxidant standards, prepared in different concentrations (2, 1, 0.5, 0.25, $0.125 \mathrm{mmol}$ Trolox/L). Plant extract TAC levels were determined with the obtained linear equation. TAC levels were expressed in mmol Trolox Equivalent/L (Erel 2004).

Determination of oxidant molecule levels in a plant may be beneficial in explaining the antioxidant capacity of the species. Furthermore, the high TOC level of the plants that would be used for phytotherapeutic purposes means that the antioxidative benefits of the plant would be reduced. Thus, total oxidant capacity (TOC) was determined in the present study. 20 $\mu \mathrm{mol} / \mathrm{L}$ hydrogen peroxide $\left(\mathrm{H}_{2} \mathrm{O}_{2}\right)$ was used as the positive control in the determination of TOC levels. Since the total antioxidant content in the plant was compared to $\mathrm{H}_{2} \mathrm{O}_{2}$, the results are presented as $\mathrm{H}_{2} \mathrm{O}_{2}$ equivalent. Sample TOC levels were determined based on the optical densities obtained with spectrophotometric readings (at $540 \mathrm{~nm}$ ) conducted after adding the reagents based on the kit protocol to plant extracts dissolved in DMSO at a concentration of $1 \mathrm{mg} /$ $\mathrm{mL}$ (Erel 2005). TOC levels were calculated using the formula indicated in the commercial kit (Rel Assay, Gaziantep, Turkey) and given below.

TOC ( $\mu$ mol $\mathrm{H}_{2} \mathrm{O}_{2}$ Equiv. $\left./ \mathrm{L}\right)=[(\triangle \mathrm{Abs}$ Sample/ $\triangle \mathrm{Abs}$ standard) $\times 20$ ]

The oxidative stress index (OSI) was calculated (Hazman \& Bozkurt 2015) with the obtained TAC and TOC data and the formula given below as provided in kit protocols. The calculated OSI values were assessed as the extract had low phytotherapeutic activity due to the low OSI levels.

$$
\text { OSI }=[(T O C / T A C) \times 100]
$$

\section{Microbiological analyses (determination of antibacterial activity)}

The antibacterial activity of Verbascum lasianthum acetone and methanol extracts were determined with the disk diffusion method. Reference strains used were Escherichia coli 0157 (ATCC 43894), Escherichia coli (ATCC 25292), Listeria monocytogenes (ATCC 7644), Salmonella typhimurium (ATCC-14028), Bacillus cereus (ATCC 11778), Staphylococcus aureus (ATCC 25923), Enterococcus faecalis (ATCC 29212) and Candida albicans (ATCC 90028).

The reference strains were counted with the nutrient broth serial dilution method. Suspensions were prepared so that the final bacteria concentration was $10^{6}-10^{7} \mathrm{cfu} / \mathrm{mL}$. $250 \mu \mathrm{L}$ bacteria culture was added to each petri dish that contained $25 \mathrm{~mL}$ of MuellerHilton agar (Oxoid CM337). $50 \mu \mathrm{L}$ extract in four different concentrations $(2.5 \%, 5 \%, 10 \%$ and 20\%) in absolute methanol were added to discs.Gentamicin $10 \mu \mathrm{g}$ (Oxoid CT0024B) and Ciprofloxacin $5 \mu \mathrm{g}$ (Oxoid CT0425B) were used as positive controls. Later was incubated at $37 \pm 2$ 
oC for 18-24 hours. The zones formed around the discs after the incubation were measured (Bauer et al. 1966, Ozkan et al. 2005). All tests were performed in duplicates with 3 samples of each extract.

\section{Cytotoxicity analyses}

Lung cancer cell line (A549), breast cancer cell line (MCF7), liver cancer cell line (HepG2) and neuroblastoma (SH-SY5Y) cells were used. The cytotoxicity levels of Verbascum lasianthum in cancer cell lines were determined with the MTT (3-4,5-dimethyl-thiazolyl-2,5diphenyltetrazolium bromide) method. The cultured cells were counted with the trypan blue method for MTT analysis. The optical densities of the samples were determined at $540 \mathrm{~nm}$ with an ELISA microplate reader (Biotek, ELx800). The cell viability of the control group, which was not treated with plant extracts, was accepted as 100\%, and the effect of each dose on cell viability was calculated with the formula presented below (Ersin et al. 2016, Ulaşlı et al. 2013).

$$
\begin{gathered}
\text { Cell viability }(\%)=\left[\left(100 * \text { Absorbance }_{\text {sample }}\right) /\right. \\
\left.\left(\text { Absorbance }_{\text {control }}\right)\right]
\end{gathered}
$$

The viability of the cells used in the application was expressed in percentage for each dose. The \% viability data obtained in MTT tests were used for determine the cytotoxic properties of the $V$. lasianthum species in cancer cells (A549, MCF-7, HepG2, SH-SY5Y cell lines). The lethal doses $\left(L_{50}\right)$, which were effective on cancer cells, were determined with the vitality rates created by each dose in cells.

\section{Mineral substance levels}

The microwave firing method was used to decompose the organic components in $V$. lasianthum samples and convert the inorganic components into a soluble form. A crude sample was placed in teflon godets. Nitric acid, hydrogen peroxide and perchloric acid were added to samples. The godets were heated in a microwave oven (Berghof). The sample minor and major element concentrations transferred to the volumetric flasks were measured with inductively coupled plasma-optical emission spectroscopy (ICP-OES; Spectro Genesis, Germany).

\section{Statistical analysis}

The collected data were presented as mean \pm standard deviation. Data analysis was conducted with SPSS 18 software. KruskalWallis test was conducted to determine the statistical differences. The statistically significant differences between the groups were determined with the Mann-Whitney U test. Epa Probit Analysis Software (Version 1.5) was used to calculate the plant extract $L_{50}$ doses that were effective in cancer (A549) cells.

\section{RESULTS AND DISCUSSION}

Verbascum lasianthum was investigated in terms of biological activity (antioxidant, antimicrobial, cytotoxic properties) and element content in the present study.

\section{Antioxidant effect}

\section{Free radical scavenging effect}

Several parameters are used as indicators of the antioxidant properties of a substance. One of the most frequent parameters is the DPPH method, an indicator of the free radical scavenging activity of the antioxidant. When the antioxidant that would be analyzed is added to the medium that contains DPPH, it neutralizes the DPPH radical and reduces the DPPH content. As the DPPH content is reduced, the absorbance is reduced 
as well. Thus, the DPPH radical scavenging activity of the substance added to the medium is calculated by reducing in the absorbance rate. In the present study, BHT and $\alpha$-tocopherol antioxidants were used to compare the effects of the analyzed extracts on the DPPH radical. In order to better understand and compare the radical scavenging activity of the plant extracts, $\mathrm{BHT}$ and $\alpha$-tocopherol that were used in this study, the graph plotted using the determined mean absorbance data is presented in Figure 1.

Based on the data above, the radical scavenging activity of $V L_{\text {methanol }}$ extract was the highest in all tested doses. When the radical scavenging activities of the $V$. lasianthum extracts and BHT and $\alpha$-tocopherol were compared, their activities can be ordered as $\mathrm{VL}_{\text {methanol }}>\mathrm{VL}_{\text {acetone }}$ $>$ BHT > $\alpha$-tocopherol (Figure 1). Verbascum lasianthum extracts, BHT and $\alpha$-tocopherol $I_{50}$ (the dose that inhibits $50 \%$ of DPPH in the environment) values, also calculated using the absorbances obtained during the determination of the radical scavenging activity (Figure 1), are presented in Table I as well.

The data demonstrated that the $I C_{50}$ value of acetone extract to inhibit DPPH radical was 17.07 $\mathrm{mg} / \mathrm{mL}$ and methanol extract $I C_{50}$ value was 6.44 $\mathrm{mg} / \mathrm{mL}$. Thus $50 \%$ of the $1 \mathrm{mM}$ concentration $\mathrm{DPPH}$ in the medium was inhibited by $6.44 \mathrm{mg} /$ $\mathrm{mL} \mathrm{VL} L_{\text {methanol }}$ extract, however $17.07 \mathrm{mg} / \mathrm{mL}$ of $V L_{\text {acetone }}$ extract could inhibit the same amount. That is, the methanol extract could neutralize the same amount of DPPH radicals at lower concentrations. Thus, the radical scavenging activity of $\mathrm{VL}_{\text {methanol }}$ extract was higher when compared to others. For comparison, BHT and $\alpha$-tocopherol could inhibit $50 \%$ of DPPH at higher concentrations when compared to plant extracts. In other words, it was found that DPPH radical scavenging activities of $\mathrm{VL}_{\text {acetone }}$ and $V L_{\text {methanol }}$ extracts were higher than BHT and $\alpha$-tocopherol.

Several studies conducted with various Verbascum species could be interpreted. The radical scavenging activity of the most frequently

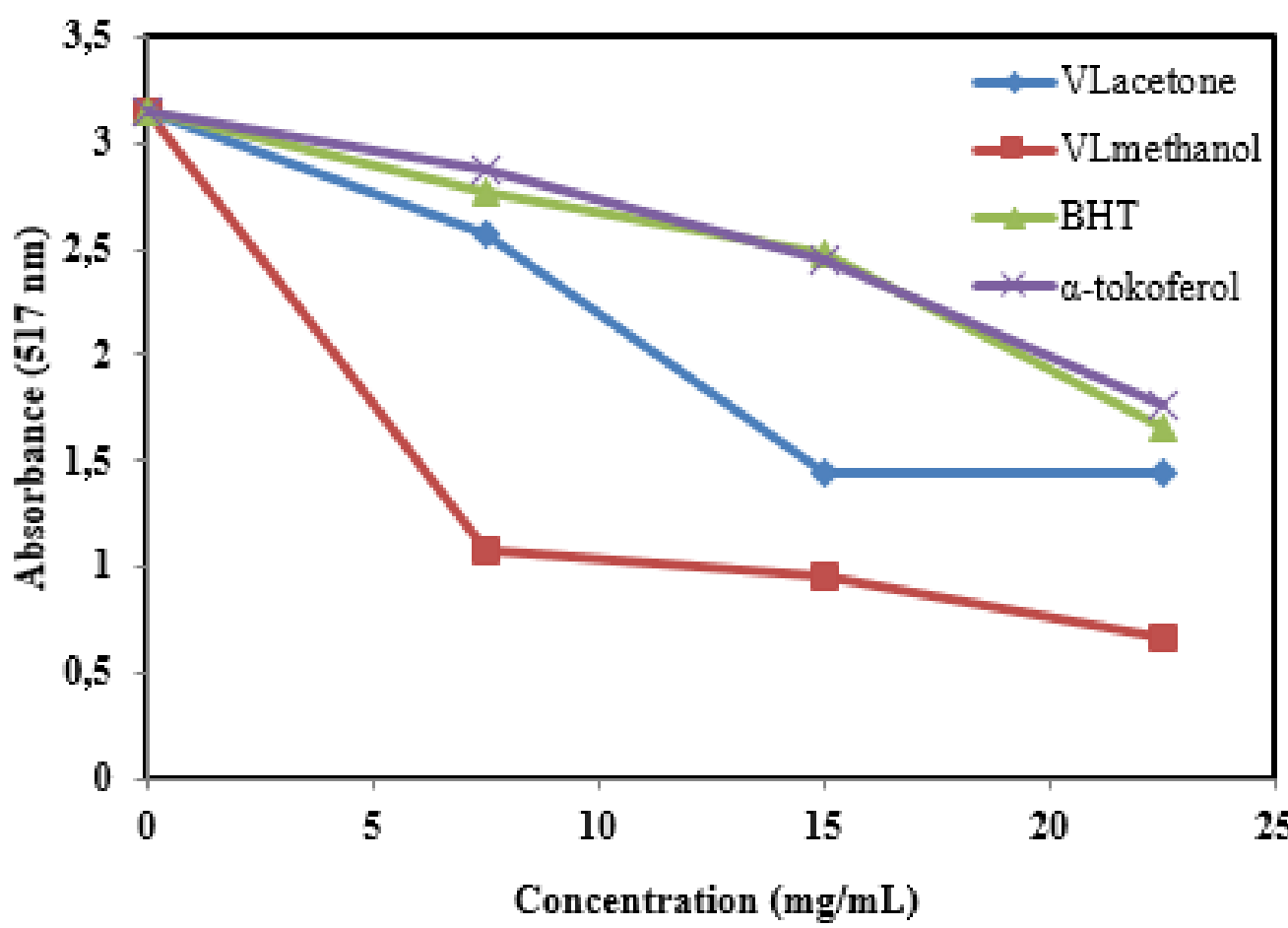

Figure 1. DPPH radical scavenging activities of different concentrations of $\mathrm{VL}_{\text {acetone, }}, \mathrm{VL}_{\text {methanol }}$ extracts and $\mathrm{BHT}$, $\alpha$-tocopherol antioxidants. 
used Verbascum L. species in drug format in developed countries, namely Verbascum thapsus was analyzed. In the methanolic extracts of the leaves of the $V$. thapsus species, it was reported that DPPH radical and NO scavenging activity $\left(\mathrm{IC}_{50}\right.$ dose for DPPH radical was approximately 80-160 $\mu \mathrm{g} / \mathrm{mL}$ ) was high (Pal et al. 2013). It was determined that the Verbascum species used in the present study, $V$. lasianthum inactivated the DPPH radical at higher doses (at $6 \mathrm{mg} / \mathrm{mL}$ levels). However, to claim this definitively, both V. thapsus and V. lasianthum samples should be analyzed under the same laboratory conditions. In another study, DPPH radical scavenging activity of Verbascum phlomoides water extract was determined. The study findings demonstrated that $\mathrm{EC}_{50}\left(I \mathrm{C}_{50}\right)$ value of the plant species was $7.09 \mathrm{mg} / \mathrm{mL}$ (Grigore et al. 2013). The present study findings also demonstrated that the DPPH radical scavenging activity of the Verbascum lasianthum species was similar to the DPPH radical scavenging activity of $V$. phlomoides, analyzed in the study by Grigore et al. (2013).

\section{Phenolic acid content, TAC, TOC and OSI levels}

It was reported in studies conducted with Verbascum species that the antioxidant

Table I. The $\mathrm{IC}_{50}$ values of BHT, $\alpha$-tocopherol antioxidants and $\mathrm{VL}_{\text {acetone }}, \mathrm{VL}_{\text {methanol }}$ extracts against the DPPH radical.

\begin{tabular}{|c|c|}
\hline Sample & Doses of $\left.\mathbf{I C}_{\mathbf{5 0}} \mathbf{( m g / m L}\right)^{*}$ \\
\hline$V L_{\text {acetone }}$ & 17.07 \\
\hline$V L_{\text {methanol }}$ & 6.44 \\
\hline $\boldsymbol{\alpha}$-tocopherol & 24.29 \\
\hline BHT & 23.58 \\
\hline
\end{tabular}

* The $\mathrm{IC}_{50}$ doses refers to the concentration of plant extract/ antioxidant which inhibits half of the $1 \mathrm{mM} 3900 \mu \mathrm{L}$ DPPH radical solution. $\left(\mathrm{VL}_{\text {metanol }}:\right.$ Verbascum lasianthum Boiss. ex Benth. methanol extract, $\mathrm{VL}_{\text {acetone }}$ : Verbascum lasianthum Boiss. ex Benth. acetone extract, BHT: Butylated Hydroxy toluene). properties of the plant extracts with high phenolic acid content could be increased (Shi et al. 2018, Ivanova et al. 2005). Polyphenols, which are very effective in forming of antioxidant properties of Verbascum species, play an active role in neutralizing oxidant molecules. Catalpol derivatives, as well as aucubin and an aucubin derivative, were isolated and characterized from the roots of $V$. lasianthum. Buddlejoside was found for the first time in the Verbascum genus in a study (Akdemir et al. 2004b). In the present study, the phenolic content $(64.47 \pm 4.84$ $\mu \mathrm{g} \mathrm{GAE} / \mathrm{mg}$ plant extract) of $\mathrm{VL}_{\text {acetone }}$ extract was higher when compared to the methanol extract $(30.82 \pm 2.10 \mu \mathrm{g}$ GAE/mg plant extract) (Table II). The findings demonstrated that the antioxidant properties increased with the high phenolic content. TAC levels of the $V L_{\text {acetone }}$ extract (2.24 $\pm 0.10 \mathrm{mmol}$ Trolox Equiv./L) with higher phenolic acid content were higher when compared to the methanol extract TAC levels (1.95 $\pm 0.12 \mathrm{mmol}$ Trolox Equiv./L). The presented data in the literature also supported these findings. It was reported that the polyphenol content of Verbascum phlomoides, which is preferred due to its sedative effects in respiratory tract diseases and inflammation in Europe, was $4.18 \%$ and thus its antioxidant effect was high (Grigore et al. 2013). The present study found that the phenolic content of $\mathrm{VL}_{\text {methanol }}$ and $V L_{\text {acetone }}$ extracts were $3.1 \%$ and $6.5 \%$, respectively. Studies conducted with other plant species demonstrated that there might be a positive correlation between plant phenolic content and antioxidant properties (Shi et al. 2018, Ivanova et al. 2005).

It can be observed in Table II that TOC and OSI levels of $V_{\text {acetone }}$ extract with high phenolic acid and TAC levels were lower when compared to the $V L_{\text {methanol }}$ extract. This finding indicated that $\mathrm{VL}_{\text {acetone }}$ extract may also have an excellent phytotherapeutic effect compared 
Table II. Phenolic acid content, and TAC, TOC and OSI levels in Verbascum lasianthum Boiss. ex Benth. extracts.

\begin{tabular}{|c|c|c|c|}
\hline & $\mathbf{V L}_{\text {methanol }}$ & $\mathbf{V L}_{\text {acetone }}$ & $\mathbf{P}$ \\
\hline $\begin{array}{c}\text { Phenolic acid content } \\
(\mu \mathrm{g} \text { GAE/mg extract })\end{array}$ & $30.82 \pm 2.10$ & $64.47 \pm 4.84$ & $0.021^{*}$ \\
\hline $\begin{array}{c}\text { TAC } \\
(\text { mmol Trolox Equivalent/L) }\end{array}$ & $1.95 \pm 0.12$ & $2.24 \pm 0.10$ & $0.021^{*}$ \\
\hline $\begin{array}{c}\text { TOC } \\
\left(\mu \text { mol } \mathrm{H}_{2} \mathrm{O}_{2} \text { Equiv./L) }\right.\end{array}$ & $71.39 \pm 6.16$ & $10.03 \pm 4.06$ & $0.021^{*}$ \\
\hline $\begin{array}{c}\text { OSI } \\
(\text { arbitrary Unit })\end{array}$ & $3681.47 \pm 458,66$ & $447.63 \pm 179.38$ & $0.021^{\star}$ \\
\hline
\end{tabular}

Datas are presented as mean \pm standard deviation $(n=4) .\left(\mathrm{VL}_{\text {metanol }}:\right.$ Verbascum lasianthum Boiss. ex Benth. methanol extract, $\mathrm{VL}_{\text {acetone: }}$ : Verbascum lasianthum Boiss. ex Benth. acetone extract, TAC: Total antioxidant capacity, TOC: Total antioxidant capacity, OSI: Oxidative stress index).

* There is a statistically significant difference between group $\mathrm{VL}_{\text {methanol }}$ and group $\mathrm{VL}_{\text {acetone }}(\mathrm{p}<0.05)$.

to the $V L_{\text {methanol }}$ extract. Because, although phytotherapeutic plants have antioxidant compounds, they also contain certain amounts of oxidants that could lead to stress. The low oxidant levels in the plant that would be used for phytotherapeutic purposes could easily be tolerated by the organism when used for phytotherapeutic purposes. This is important for the more substantial benefits of the effects of antioxidant components in a plant species.

\section{Mineral levels}

Plants' mineral content is the critical reason for their antioxidant properties. Because the plants and their extracts with sufficient essential trace elements for the human body could support the immune system. Bio-elements are required for the synthesis, storage, activity or degradation of the biomolecules such as several enzymes, vitamins and hormones, which are essential for the metabolism balance. Thus, the bioelement content of Verbascum lasianthum was determined in the present study. The findings demonstrated that $V$. lasianthum had a rich mineral content (Table III). Especially it could be argued that the high level of trace bio-element content such as zinc, copper, manganese and iron, could have improved the antioxidant capacity of the plant. Because iron, which is one of the essential elements, is included in the structure of hemoglobin and also participates in the catalase structure, which is a significant antioxidant enzyme for the immune system. Copper is an important bio-element in the absorption and transportation of iron. Mn or $\mathrm{Cu}$-Zn trace elements are required as co-factors for the activity of superoxide dismutase (SOD) enzyme, which is synthesized in the metabolism and has antioxidative activities (Reiter et al. 2000). It was reported that the deficiency of Mn mineral, a SOD enzyme cofactor, stimulates lipid peroxidation and oxidative stress (Paynter 1980). Other SOD enzyme cofactors, Cu and Zn minerals support the antioxidant system, and play roles in growth, immune system, cellular respiration, redox processes and protein synthesis (Valko et al. 2005). Thus, the bio-elements such as Fe, $\mathrm{Cu}, \mathrm{Mn}, \mathrm{Zn}, \mathrm{Mg}$ found in V. lasianthum positively affect the antioxidant system of the organism and on other mechanisms responsible for the regulation of the metabolism. 
Table III. The element levels in the Verbascum lasianthum Boiss. ex Benth.

\begin{tabular}{|c|c|c|c|}
\hline Elemen & Concentration (ppm) & Element & Concentration (ppm) \\
\hline $\mathbf{F e}$ & $446.98 \pm 94.63$ & $\mathbf{N a}$ & $78.38 \pm 10.08$ \\
\hline $\mathbf{C u}$ & $6.94 \pm 0.91$ & $\mathbf{C a}$ & $4409.43 \pm 447.33$ \\
\hline $\mathbf{M n}$ & $38.12 \pm 2.39$ & $\mathbf{M g}$ & $1386.76 \pm 142.82$ \\
\hline Zn & $20.67 \pm 1.08$ & $\mathbf{B a}$ & $9.45 \pm 0.79$ \\
\hline $\mathbf{C r}$ & $0.72 \pm 0.11$ & $\mathbf{N i}$ & $1.72 \pm 0.09$ \\
\hline $\mathbf{B}$ & $0.14 \pm 0.01$ & $\mathbf{B i}$ & $8.66 \pm 0.42$ \\
\hline Se & undetected* & $\mathbf{G a}$ & $0.24 \pm 0.05$ \\
\hline Co & undetected* & $\mathbf{P b}$ & $3.08 \pm 0.78$ \\
\hline
\end{tabular}

Datas are presented as mean \pm standard deviation $(n=5)$.

${ }^{*}$ Concentrations of elements with little or no values in the plant (Se, Te, Tl, Be, Co, Cd, Li) could not be determined.

One of the interesting findings in the present study was the gallium, boron and bismuth content of the $\mathrm{V}$. lasianthum, albeit in low concentrations. The gallium ( $\mathrm{Ga}$ ) element is not found in nature in pure form. It is one of the elements used in the production of semiconductor material and infrared receivers. A review of the studies that investigated the mineral levels in various plant species would demonstrate that there are very few plant species with gallium content. In the future, the gallium content of $V$. lasianthum could be significant as science would advance and the use of gallium and its effects on human health are known. Boron compounds are known to have low toxicity levels (Hubbard 1998). Studies with certain boron compounds demonstrated that it may have beneficial effects on various pathologies and diseases (Hazman et al. 2018, Çoban et al. 2015, Ince et al. 2012). Thus, V. lasianthum boron content may also contribute to its phytotherapeutic activities. The bismuth content of the plant, which was identified as $8.66 \mathrm{ppm}$ in the present study, is known to have clinical benefits at low doses. Bismuth, known to have antimicrobial properties, is one of the ingredients of certain drugs used in the treatment of peptic ulcer (as Bismuth subsalicylate and bismuth subcitrate) (Ko et al. 2019, Kim et al. 2019). However, it should be remembered that Bismuth has neurotoxic effects in high doses and may lead to the development of symptoms such as encephalopathy, aphasia and myoclonus (Sampognaro et al. 2017, Hogan et al. 2018).

Several Verbascum L. species naturally grow in Turkey, especially during June and September in regions with an altitude of about 600-1700 in roadside fields. This can be explained by the effect of the heavy metals that accumulate in the soil, probably due to the vehicles passing through the roads on Verbascum species. In the present study the $V$. lasianthum was collected in a field located at a distance of a few kilometers from the road on the $38^{\text {th }} \mathrm{km}$ of Afyon-Ankara highway (B3 Afyonkarahisar, Bayat, Köroğlubeli pass, an opening in "Cistus laurifolius" bushes), and the analyses demonstrated that it included certain amounts of heavy metals such as Pb, 
$\mathrm{Cr}$, and $\mathrm{Cd}$. In a previous study, it was reported that after metal contamination of the soil, Verbascum species could adapt by developing metal tolerance shortly after exposure. Thus they have phytostabilization potential (Morina et al. 2016). In another study that investigated the decontamination of the soil with heavy metal content with various plants, it was reported that the Verbascum thapsus L. species accumulated soil-borne heavy metals and led to biomass regeneration and it was a plant with phytoextraction potential. In a study conducted with five plant species, Populus ssp., Ailanthus glandulosa L., Robinia pseudoacacia L., Artemisia artemisiifolia L. and Verbascum thapsus L. species were used. The findings of the study that was conducted for 5 years demonstrated that Verbascum thapsus species was more effective in biomass production and heavy metal removal ( $\mathrm{Pb}, \mathrm{Cd}, \mathrm{Zn}, \mathrm{Cu}, \mathrm{Ni}, \mathrm{Cr}$ and $\mathrm{As}$ ) in a polluted area, and thus reduced the mean soil pollution (Cudic et al. 2016). Based on this data, it could be suggested that Verbascum lasianthum and other Verbascum species could contribute to the reduction of heavy metal contamination in the soil through phytoextraction and phytostabilization (vegetative fixation; reduction of the bioavailability of toxic metals and other pollutants by the plant).

\section{Antibacterial potential}

Antibacterial properties of Verbascum lasianthum were determined using standard gram-positive, gram-negative bacteria and yeast strains with both acetone and methanol extracts. The data are presented in Table IV. As seen in Table IV, all concentrations of Verbascum lasianthum acetone extract did not affect $L$. monocytogenes, B. cereus, E. faecalis, E. coli 0157 and S. typhimurium, however they were effective on S. aureus, E. coli and C. albicans. The literature review revealed no previous studies on antimicrobial activities of the acetone extract

Table IV. Antibacterial activity of Verbascum lasianthum Boiss. ex Benth. species.

\begin{tabular}{|c|c|c|c|c|c|c|c|c|c|c|}
\hline & \multirow{2}{*}{$\begin{array}{c}\text { Gentamicin } \\
(10 \mu g)\end{array}$} & \multirow{2}{*}{ 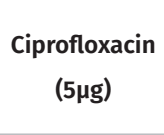 } & \multicolumn{4}{|c|}{$\begin{array}{l}\text { The dose of applied acetone extract of } \\
\text { Verbascum* }\end{array}$} & \multicolumn{4}{|c|}{$\begin{array}{l}\text { The dose of applied methanol extract } \\
\text { of Verbascum* }\end{array}$} \\
\hline & & & $2.5 \%$ & $5 \%$ & $10 \%$ & $20 \%$ & $2.5 \%$ & $5 \%$ & $10 \%$ & $20 \%$ \\
\hline $\begin{array}{l}\text { L. } \\
\text { monocytogenes }\end{array}$ & $16.67 \pm 0.58$ & $30.33 \pm 1.15$ & 0 & 0 & 0 & 0 & 0 & 0 & 0 & $12 \pm 1$ \\
\hline B. cereus & $27.33 \pm 0.58$ & $30.66 \pm 1.15$ & 0 & 0 & 0 & 0 & 0 & 0 & 0 & 0 \\
\hline S. aureus & $19.66 \pm 2.51$ & $22.66 \pm 2.08$ & 0 & 0 & $10.33 \pm 0.58$ & $10.33 \pm 0.58$ & 0 & 0 & 0 & 0 \\
\hline E. faecalis & $14.66 \pm 2.08$ & $21.33 \pm 1.15$ & 0 & 0 & 0 & 0 & 0 & 0 & 0 & 0 \\
\hline E. coli & $18 \pm 1$ & $27.66 \pm 0.58$ & 0 & $8.66 \pm 0.58$ & $10.66 \pm 1.15$ & $12.66 \pm 0.58$ & 0 & 0 & 0 & $\begin{array}{c}11.33 \pm \\
1.15\end{array}$ \\
\hline E. coli 0157 & $15.33 \pm 1.15$ & $27.66 \pm 1.15$ & 0 & 0 & 0 & 0 & 0 & 0 & 0 & 0 \\
\hline S. typhimurium & $15.66 \pm 1.52$ & $31 \pm 1$ & 0 & 0 & 0 & 0 & 0 & 0 & $\begin{array}{c}10.33 \pm \\
0.58\end{array}$ & $11 \pm 1$ \\
\hline C. albicans & $15 \pm 1$ & $29.33 \pm 0.58$ & 0 & $12.33 \pm 0.58$ & $16.33 \pm 0.58$ & $18.33 \pm 0.58$ & 0 & 0 & 0 & $\begin{array}{c}12.66 \pm \\
0.58\end{array}$ \\
\hline
\end{tabular}

Datas are presented as mean \pm standard deviation $(n=3)$. Antibacterial activity was determined using disk diffusion method. * Different concentrations of extracts prepared in solutions ( $w / v ; 2.5 \%, 5 \%, 10 \%$ ve $20 \%)$ in absolated methanol ( $50 \mu \mathrm{L}$ ) were added to discs. Absolute ethanol, Gentamicin $10 \mu \mathrm{g}$ (Oxoid CT0024B) and Ciprofloxacin $5 \mu \mathrm{g}$ (Oxoid CT0425B) were used as controls. Reference strains used; Escherichia coli 0157 (ATCC 43894), Escherichia coli (ATCC 25292), Listeria monocytogenes (ATCC 7644), Salmonella typhimurium (ATCC-14028), Bacillus cereus (ATCC 11778), Staphylococcus aureus (ATCC 25923), Enterococcus faecalis (ATCC 29212) and Candida albicans (ATCC 90028). 
of this plant. Thus, the findings of the present study were the first in the literature.

Previous studies investigated the antimicrobial activity of Verbascum lasianthum Boiss. ex Benth. methanol extracts (Kahraman et al. 2011). In the related study, three bacteria (S. aureus, E. coli, P. aeruginosa) and three yeast strains (C. albicans, C. krusei, C. parapsilosis) were used and it was reported that $V$. lasianthum plantwas not effective on S. aureus, E. coli and C. albicans strains. In the present study, six bacterial strains and one yeast strain were used. The findings demonstrated that all concentrations of the $V$. lasianthum methanol extract did not have any effect on B. cereus, S. aureus, E. faecalis and E. coli 0157. It was determined that especially $20 \%$ concentrations of methanol extracts were effective on L. monocytogenes, E. coli, S. typhimurium and C. albicans. However, in a study conducted by Kahraman et al. (2011), it was reported that $V$. lasianthum had no effects on $E$. coli and C. albicans strains. Differences between the present study findings and the findings mentioned in the literature could be explained by the differences between the high and low concentrations used in these studies. Because, in the present study, the extracts prepared in 4 dilution rates were applied to $50 \mu \mathrm{L}$ bacterial strains, while the previous study reported that a $200 \mu \mathrm{g}$ dose was used in $20 \mathrm{~mL}$ volume.

\section{Cytotoxic properties}

Different concentrations (25, 50, 100, 200, 500, $1000,2000 \mu \mathrm{g} / \mathrm{mL}$ ) of both methanol and acetone extracts of $V$. lasianthum were used to investigate cytotoxic properties of the species on various cancer cell lines (A549, MCF7, SH-SY5Y and HepG2). The findings demonstrated that a clear cytotoxic effect was observed only on the A549 cell line (Figure 2a). The calculations revealed that the $L_{50}$ doses of Verbascum lasianthum in the A549 cell line were $652.8 \mu \mathrm{g}$
/ $\mathrm{mL}$ for the acetone extract and $939.2 \mu \mathrm{g} / \mathrm{mL}$ for the methanol extract. It was determined that doses of both methanol and acetone extracts that were applied to the A549 cells (even at the lowest dose of $25 \mu \mathrm{g} / \mathrm{mL}$ ) were cytotoxic (anti-proliferative). The compounds called luteolin and 3-O-fucopyranosylsaikogenin F, isolated from another Verbascum species, Verbascum thapsus, were reported to have an anticarcinogenic effect by inducing apoptosis in A549 cells (Zhao et al. 2011). This data could explain the possible reasons for the cytotoxic properties of $V$. lasianthum on A549 cells in the present study and supporting the previous findings. Because the presence of several bioactive compounds such as saponin, cataptol, ajugol, sinuatol, verbascoside, and especially luteolin, known to have apoptotic effects on A549 cells (Zhao et al. 2011) in different extracts of $\mathrm{V}$. lasianthum is known (Akdemir et al. 2004a, Kupeli et al. 2007, Tatlı et al. 2007). However, further studies are required to determine which components are effective to extending and on what types of cancer.

The present study findings demonstrated that all doses increased the proliferation in cancer cells, contrary to the cytotoxic effects of Verbascum lasianthum on HepG2 cells (Figure 2c). Similarly, Figure $2 \mathrm{~b}$ demonstrates that low doses of acetone and methanol extracts increased the viability of MCF-7 cancer cells. It was determined that only high methanol extract doses (1000 and $2000 \mathrm{\mu g} / \mathrm{mL}$ ) could have cytotoxicity in MCF 7 cells, albeit low. Although there is no literature on the effect of $V$. lasianthum on cancer cell lines, certain studies investigated the impact of various Verbascum species on MCF-7 and HepG2 cells. The anticarcinogenic effects of Verbascim sinaiticum L. species on both HepG2 and MCF-7 cells were investigated, and it was reported that it was not possible to determine the effects on HepG2 cells. In MCF-7 cells, it was determined that 
a

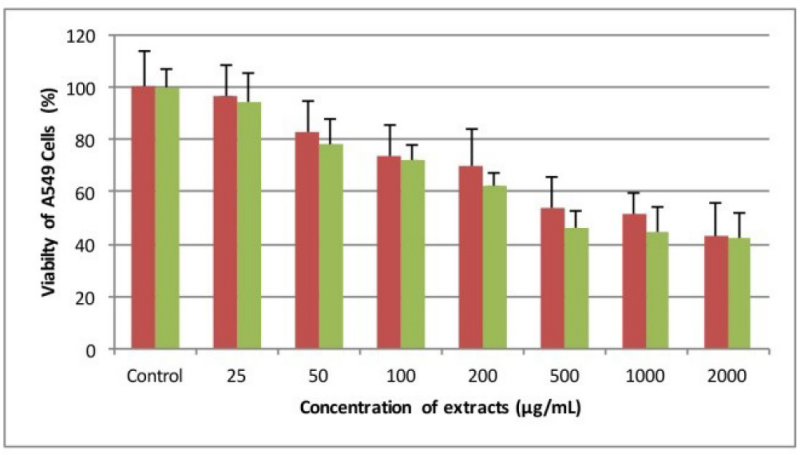

Methanol extract

\section{C}

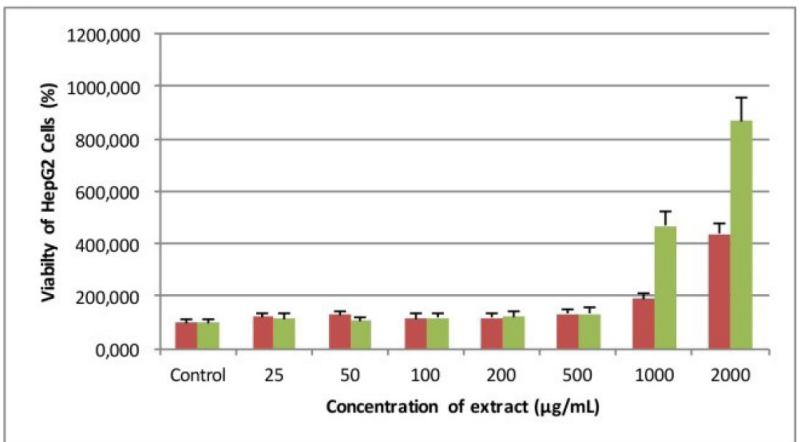

b

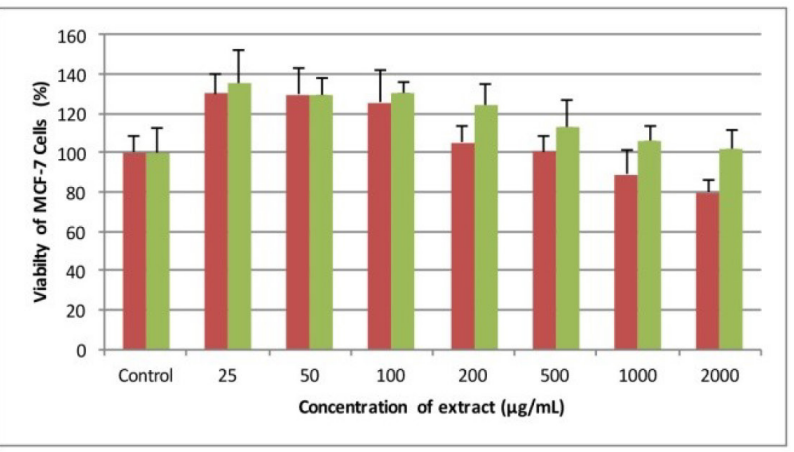

Acetone extract

d

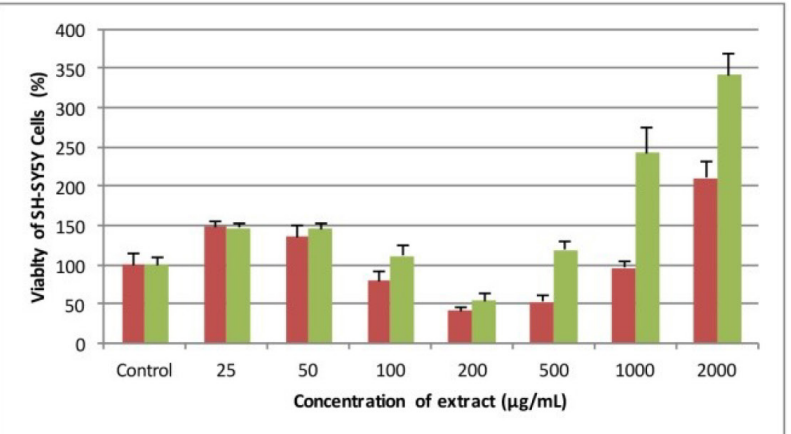

Figure 2. The effect of Verbascum lasianthum Boiss. ex Benth. extracts on cancer cells (A549, MCF-7, HepG2 and SHSY5Y cell lines).

the methanol, hexane and chloroform extracts of $V$. sinaiticum L. species were antiproliferative, while water and n-butanol extracts were proliferative (Talib \& Mahasneh 2010).

In the SH-SY5Y cell line consisting of neuroblastoma cells, it was found that certain doses of the acetone and methanol extracts of $V$. lasianthum demonstrated cytotoxic effects (especially $200 \mu \mathrm{g} / \mathrm{mL}$ ), while they had proliferative effects in certain other doses (low and high doses) (Figure 2d). Although there are no previous studies on the effects of Verbascum species on SH-SY5Y cells, a study investigated the effect of a compound called acteoside, which is a verbascoside compound isolated from verbascum sinuatum, on neuroblastoma cells. In that study, it was reported that the compound isolated from $V$. sinuatum inhibited apoptosis in SH-SY5Y cells within the range of 0-40 $\mu \mathrm{g} /$ $\mathrm{mL}$ (Wang et al. 2009). These data support the results obtained in the present study. Because the current study data demonstrated that $V$. lasianthum methanol and acetone extracts that contain verbascoside compounds (Akdemir et al. 2004a) increased the proliferation in SHSY5Y cells up to a concentration of $50 \mu \mathrm{g} / \mathrm{mL}$. One of the reasons for this could be related to the inhibition of apoptosis by verbascoside compounds (Wang et al. 2009).

\section{CONCLUSION}

In the present study, it was determined that Verbascum lasianthum Boiss. ex Benth. species could increase proliferation in cancer lines other than A549 cell line, thus demonstrating that it is 
necessary to decide on fine boundaries for the use of this plant species. Therefore, the effect of antioxidant plants or bioactive compounds on cancer cells, whose phytotherapeutic effects are investigated, should be defined. Furthermore, the cytotoxic properties of $V$. lasianthum against the lung cancer (A549) cell line, associated with the respiratory system, were engaging in particular. This finding may be related to using the Verbascum species in respiratory tract diseases phytotherapeutically due to their mucolytic effects.

In conclusion, determination of the ethnopharmacological properties of Verbascum L. species, whose economic value is increasing every day due to their effects on diseases, and represented with about 360 species globally, could contribute to the development of innovative products in this field. Even the primary phase studies have not been conducted on most Verbascum L. species. It is essential to determine the species whose effects have not been analyzed and to conduct the required studies. Only then, clinically effective species would be identified, and related products could be developed.

\section{Acknowledgments}

We declare that, this study was financially supported by Scientific Research Projects Committee (project number: 16.FENED.ALTY.01), Rectorate of Afyon Kocatepe University, Afyonkarahisar, Turkey.

\section{REFERENCES}

AKDEMIR Z, KAHRAMAN C, TATLI II, KUPELI AKKOL E, SÜNTAR I \& KELES H. 2011. Bioassay-guided isolation of antiinflammatory, antinociceptive and wound healer glycosides from the flowers of Verbascum mucronatum Lam. J Ethnopharmacol 136: 436-443.

AKDEMIR Z, TATLI II, BEDIR E \& KHAN IA. 2004b. Acylated Iridoid Glycosides from Verbascum lasianthum Turk J Chem 28: 101-109.
AKDEMIR ZŞ, TATLI I, BEDIR E \& KHAN IA. 2004a. Iridoid and Phenylethanoid Glycosides from Verbascum lasianthum. Turk J Chem 28: 227-234.

ALIPIEVA KI, ORHAN IE, CANKAYA IIT, KOSTADINOVA EP \& GEORGIEV MI. 2014. Treasure from garden: chemical profiling, pharmacology and biotechnology of mulleins. Phytochem Rev 13: 417-444.

BANI B, ADIGUZEL N \& KARAVELIOGULLARI FA. 2010. Verbascum turcicum (Scrophulariaceae), a New Species from Turkey. Ann Bot Fenn 47: 489-492.

BAUER RW, KIRBY MDK, SHERRIS JC \& TURCK M. 1966. Antibiotic susceptibility testing by standard single disc diffusion method. Am J Clin Pathol 45: 493-496.

CUDIC V, STOJILJKOVIC D \& JOVOVIC A. 2016. Phytoremediation potential of wild plants growing on soil contaminated with heavy metals. Arh Hig Rada Toksikol 67: 229-239.

ÇOBAN FK, LIMAN R, CIGERCI IH, HAZMAN O, INCE S \& BOZKURT MF. 2015. The antioxidant effects of boron on oxidative stres and DNA damage in diabetic rats. Fresenius Environ Bull 24: 4059-4066.

DESMARCHELIER C, BERMUDEZ MJN, COUSSIO J, CICCIA G \& BOVERIS A. 1997. Antioxidant and prooxidant activities in aqueous extract of Argentine plants. Int I Pharmacogn 35: $116-120$.

EREL O. 2004. A novel automated method to measure total antioxidant response against potent free radical reactions. Clin Biochem 37: 112-119.

EREL O. 2005. A new automated colorimetric method for measuring total oxidant status. Clin Biochem 38 : $1103-1111$.

ERSIN G, ÇELIK S, ULASLI SS, OZYUREK A, HAZMAN O, GUNAY S, OZDEMIR M \& UNLU M. 2016. Comparison of the Antiinflammatory Effects of Proanthocyanidin, Quercetin, and Damnacanthal on Benzo(a)pyrene Exposed A549 Alveolar Cell Line. Inflamm 39: 744-751.

GAMEZ MEZA N, NORIEGA RODRIGUEZ JA, MEDINA JUAREZ LA, ORTEGA GARCIA J, CAZAREZ CASANOVA R \& ANGULO GUERRERO O. 1999. Antioxidant activity in soybean oil of extracts from thompson grape bagasse. J Am Oil Chem' Soc 76: 1445-1447.

GRIGORE A, COLCERU MIHUL S, LITESCU S, PANTELI M \& RASIT I. 2013. Correlation between polyphenol content and anti-inflammatory activity of Verbascum phlomoides (mullein). Pharm Biol 51: 925-929.

HAZMAN O \& BOZKURT MF. 2015. Anti-inflammatory and Antioxidative Activities of Safranal in the Reduction of 
Renal Dysfunction and Damage that Occur in Diabetic Nephropathy. Inflamm 38: 1537-1545.

HAZMAN O, BOZKURT MF, FIDAN AF, UYSAL FE \& ÇELIK S. 2018. The Effect of Boric Acid and Borax on Oxidative Stress, Inflammation, ER Stress and Apoptosis in Cisplatin Toxication and Nephrotoxicity Developing as a Result of Toxication. Inflamm 3: 1032-1048.

HOGAN DB, HARBIDGE C \& DUNCAN A. 2018. Bismuth Toxicity Presenting as Declining Mobility and Falls. J Am Geriatr Soc 21: 307-309.

HUBBARD SA. 1998. Comparative Toxicology of Borates. Biol Trace Elem Res 66: 343-357.

INCE S, KELES H, ERDOGAN M, HAZMAN O \& KUÇUKKURT I. 2012. Protective effect of boric acid against carbon tetrachloride-induced hepatotoxicity in mice. Drug and Chemical Toxicology Drug Chem Toxicol 35: 285-292.

IVANOVA D, GEROVA D, CHERVENKOV T \& YANKOVA T. 2005. Polyphenols and antioxidant capacity of Bulgarian medicinal plants. J Ethnopharmacol 96: 145-150.

KAHRAMAN C, EKIZOGLU M, KART D, AKDEMIR AS \& TATLI II. 2011. Antimicrobial Activity of Some Verbascum Species Growing in Turkey. Fabad J Pharm Sci 36: 11-15.

KAHRAMAN C, TATLI I, ORHAN IE \& AKDEMIR ZS. 2010. Cholinesterase inhibitory and antioxidant properties of Verbascum mucronatum Lam. and its secondary metabolites. Z Naturforsch C 65: 667-674.

KIM SE, ROH JH, PARK MI, PARK SJ, MOON W, KIM JH, JUNG K \& HEO JJ. 2019. Effect of 7-day Bismuth Quadruple Therapy versus 14-day Moxifloxacin Triple Therapy for Secondline Helicobacter pylori Eradication Therapy. Korean J Gastroenterol 73: 26-34.

KO SW, KIM YJ, CHUNG WC \& LEE SJ. 2019. Bismuth supplements as the first-line regimen for Helicobacter pylori eradication therapy: Systemic review and metaanalysis. Helicobacter 24: e12565.

KUPELI E, TATLI II, AKDEMIR ZS \& YESILADA E. 2007. Bioassay-guided isolation of anti-inflammatory and antinociceptive glycoterpenoids from the flowers of Verbascum lasianthum Boiss. ex Bentham. J Ethnopharmacol 110: 444-450.

LUCA SV, MIRON A, APROTOSOAIE AC, MIHAI CT, VOCHITA G, GHERGHEL D, CIOCARLAN N \& SKALICKA-WOŹNIAK K. 2019. HPLC-DAD-ESI-Q-TOF-MS/MS profiling of Verbascum ovalifolium Donn ex Sims and evaluation of its antioxidant and cytogenotoxic activities. Phytochem Anal 30: 34-45.
MORINA F, JOVANOVIC L, PROKIC L, VELJOVIC JOVANOVIC S \& SMITH JAC. 2016. Physiological basis of differential zinc and copper tolerance of Verbascum populations from metal-contaminated and uncontaminated areas. Environ Sci Pollut Res 23: 10005-10020.

OZKAN G, SAGDIC O, OZCAN M, OZCELIK H \& UNVER A. 2005. Antioxidant and antibacterial activities of Turkish endemic Sideritis extracts. Grasas Aceites 56: 16-20.

PAL H, KUMAR T \& KARKI H. 2013. In vitro antioxidant and renoprotective potential of methanolic extracts of Verbascum Thapsus leaf in rats. Der Pharmsin 4: 113-122.

PAYNTER DI. 1980. The role of dietary copper, manganese, selenium, and vitamin $\mathrm{E}$ in lipid peroxidation in tissues of the rat. Biol Trace Elem Res 2: 121-135.

REITER RJ, TAN DX, OSUNA C \& GITTO E. 2000. Actions of melatonin in the reduction of oxidative stress: a review. J Biomed Res 7: 444-458.

SAMPOGNARO P, VO KT, RICHIE M, BLANC PD \& KEENAN K. 2017. Bismuth subgallate toxicity in the age of online supplement use. Neurologist 22: 237-240.

SHI P, DU W, WANG Y, TENG X, CHEN X \& YE L. 2018. Total phenolic, flavonoid content, and antioxidant activity of bulbs, leaves, and flowers made from Eleutherine bulbosa (Mill.) Urb. Food Sci Nutr 7: 148-154.

SUNTAR I, TATLI I, KUPELI AE, KELEŞ H, KAHRAMAN Ç \& AKDEMIR Z. 2010. An ethnopharmacological study on Verbascum species: from conventional wound healing use to scientific verification. J Ethnopharmacol 132: 408-413.

TALIB WH \& MAHASNEH AM. 2010. Antiproliferative activity of plant extracts used against cancer in traditional medicine. Sci Pharm 78: 33-45.

TATLI II, TAKAMATSU S, KHAN I \& AKDEMIR ZS. 2007. Screening for free radical scavenging and cell aggregation inhibitory activities by secondary metabolites from Turkish Verbascum species. Z Naturforsch C 62: 673-678.

TUZLACI E \& EROL MK. 1999. Turkish folk medicinal plants. Part II. Egirdir (Isparta). Fitoterapia 70: 593-610.

ULAŞLI SS, CELIK S, GUNAY E, OZDEMIR M, HAZMAN O, OZYUREK A, KOYUNCU T \& UNLU M. 2013. Anticancer Effects of Thymoquinone, Caffeic Acid Phenethyl Ester and Resveratrol on A549 Non-small Cell Lung Cancer Cells Exposed to Benzo(a)pyrene. Asian Pac J Cancer Prev 14: 6159-6164.

VALKO M, MORRIS H \& CRONIN MTD. 2005. Metals, toxicity and oxidative stress. Curr Med Chem 12: 1161-1208.

WANG H, XU Y, YAN J, ZHAO X, SUN X, ZHANG Y, GUO J \& ZHU C. 2009. Acteoside protects human neuroblastoma SH-SY5Y 
cells against beta-amyloid-induced cell injury. Brain Res 1283: 139-147.

ZHAO YL, WANG SF, LI Y, HE QX, LIU KC, YANG YP \& LI ZL. 2011. Isolation of chemical constituents from the aerial parts of Verbascum thapsus and their antiangiogenic and antiproliferative activities. Arc Pharm Res 34: 703-707.

\section{How to cite}

HAZMAN Ö, AKSOY L, BÜYÜKBEN A, KARA R, KARGIOĞLU M, KUMRAL ZB \& IBRAHIM E. 2021. Evaluation of antioxidant, cytotoxic, antibacterial effects and mineral levels of Verbascum lasianthum Boiss. ex Bentham. An Acad Bras Cienc 93: e20210865. DOI 10.1590/0001-3765202120210865.

Manuscript received on January 13, 2021;

accepted for publication on August 13, 2021

ÖMER HAZMAN ${ }^{1}$

https://orcid.org/0000-0002-2702-6847

\section{LAÇINE AKSOY ${ }^{1}$}

https://orcid.org/0000-0001-8086-5079

\section{AHMET BÜYÜKBEN ${ }^{2}$}

https://orcid.org/0000-0002-5639-7217

\section{RECEP KARA ${ }^{3}$}

https://orcid.org/0000-0002-9257-7506

\section{MUSTAFA KARGIOĞLU 4}

https://orcid.org/0000-0003-0386-9716

\section{ZEHRA B. KUMRAL 1}

https://orcid.org/0000-0002-6909-9307

\section{IBRAHIM EROL ${ }^{1}$}

https://orcid.org/0000-0002-5541-8354

${ }^{1}$ Afyon Kocatepe University, Faculty of Science and Arts, Department of Chemistry, Afyonkarahisar, Turkey

${ }^{2}$ Program of Chemistry Technology, Afyon Kocatepe University, Afyonkarahisar, Cay Vocational School, Turkey

${ }^{3}$ Afyon Kocatepe University, Faculty of Veterinary Medicine, Department of Food Hygiene and Technology, Afyonkarahisar, Turkey

${ }^{4}$ Afyon Kocatepe University, Faculty of Science and Arts, Department of Molecular Biology and Genetics, Afyonkarahisar, Turkey

Correspondence to: Laçine Aksoy

E-mail: lacinetur@aku.edu.tr

\section{Author contributions}

Ömer Hazman, Laçine Aksoy, Mustafa Kargığlu and ibrahim Erol contributed to the study by conducting the study, experimental design and project design. Laçine Aksoy, Ömer Hazman, Ahmet Büyükben, and Zehra Betül Kumral have contributed to biochemical laboratory studies. Recep Kara has contributed to microbiological analysis. Ömer Hazman, Laçine Aksoy, Mustafa Kargıoglu and ibrahim Erol have contributed to data analysis.

\section{(cc) BY}

